BENHA VETERINARY MEDICAL JOURNAL, VOL. 29, NO. 2:230-234, DECEMBER,

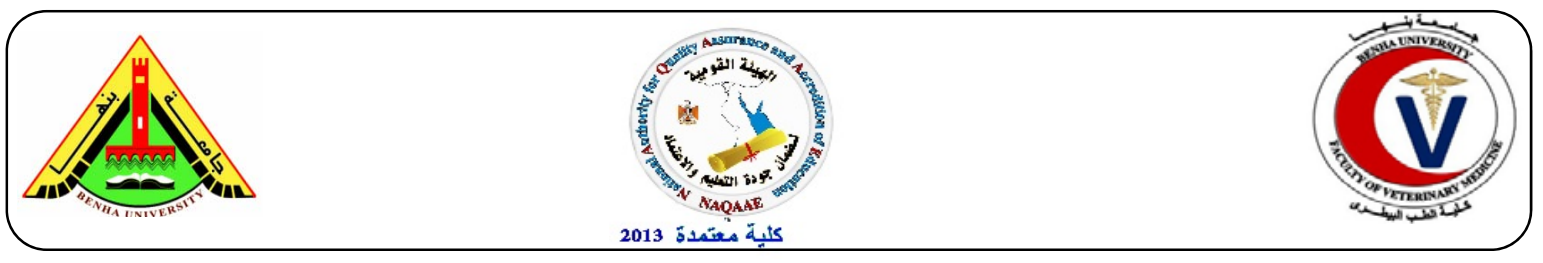

\title{
Pesticide Residues in Some Salted Fish
}

\author{
Saad S.M ${ }^{1}$, Edris A.M ${ }^{1}$, Amani M. Salem ${ }^{1}$, Enas A. Hassan ${ }^{2}$, Eman M. Mostafa ${ }^{3}$ \\ ${ }^{1}$ Food Control Dept., Faculty of Veterinary Medicine, Benha University. ${ }^{2}$ Animal Health Research \\ Institute, Benha Branch. ${ }^{3}$ Kafr Shokr Veterinary Administration
}

\section{A B S T R A C T}

A total of 90 random samples of salted fish products represented by salted sardine, salted Mugil cephalus (fesiekh) and salted Hydrocynus froskahlii (Mellouha) (30 of each) were collected from different supermarkets at El-Kalyoubia governorate. The collected samples were directly transferred to the laboratory for determination of Malathion and dieldrin. The obtained results indicated that the mean values of malathion concentration in the examined samples of slated sardine, salted Mugil cephalus and salted Hydrocynus froskahliii were 0, 206.35 \pm 11.59 and $318.05 \pm 23.31 \mathrm{ppb}$, respectively. Also, the obtained results indicated that the mean values of dieldrin concentration in the examined samples of salted sardine, salted Mugil cephalus and salted Hydrocynus froskahlii were 38.2, $164.40 \pm 9.31$ and $218.92 \pm 15.07 \mathrm{ppb}$, respectively.

Key words: Pesticides, salted fish products

(http://www.bvmj.bu.edu.eg)

(BVMJ-29(2): 230-234, 2015)

\section{INTRODUCTION}

$\mathrm{F}$ ish has been recognized as an ideal food containing high quality protein and fat that are completely digested and assimilated in the body than that of any other foods. Fish oils are rich sources of essential fatty acids those have beneficial health effects in the prevention of a number of diseases such as coronary heart diseases, inflammation, autoimmune disorders and cancer. However, there is substantial evidence that fish and seafood are high on the list of foods associated with outbreaks of foodborne diseases. Salted fish products are popular in many countries around the world. Salting is one of the oldest techniques for fish preservation, and is essentially intended to increase the shelf life of the product depressing water activity by means of dehydration and salty uptake by the fish muscle. In addition, Sodium chloride is a flavor enhancer as a consequence of its effect on different biochemical mechanisms by reducing or enhancing the enzymatic activity of some enzymes responsible for the development of different organoleptic parameters. However, the current demand for salted fish is driven more by the flavor of the product than for preservation purpose. The current widespread use of potent pesticides has created potential toxic hazards for both man and animals. There has been increasing concern about the possible harmful effects resulting from accumulation of these chemicals in soil, water and animal feed (Schafer and Kegley, 2002). They constitute severe threat to human health due to their cumulative nature resulting in cancer, renal failure, human hypertension, neuropathy of both central and peripheral nervous system, gastroenteritis, diabetes mellitus, anemia and osteomalacia (Klopov, 1998). Organophosphorus pesticides such as malathion are less persistent than organochlorine type as dieldrin and many of them appreciably affect the different stages 
of animal development. These compounds have short persistence, and they could be changed into metabolites which mostly more toxic than the original compounds (Bedi et al., 2007). Generally, most of the pesticides are toxic to all forms of life and very widely used in different degrees lead to possible hazards when they present.

The present work was carried out to determine the residual concentrations of malathion and dieldrin in such salted fish products.

\section{MATERIAL AND METHODS}

\subsection{Collection of samples}

A total of 90 random samples of salted fish products represented by salted sardine, salted Mugil cephalus (Fesiekh) and salted Hydrocynus froskahlii (Mellouha) (30 of each) were collected from different supermarkets at El-Kalyoubia governorate. The samples were directly transferred to the laboratory to determine malathion and dieldrin content.

\subsection{Determination of organochlorine pesticide residues (Dieldrin) according to AOAC (1990).}

Extraction of fish samples: Extraction of tissue samples was conducted as described by Abdel Kader (1989). Partitioning: Partitioning of extracted fish samples was carried out according to Leon et al. (1990). Clean up: The cleanup of extracted fish samples was conducted according to Mills et al. (1972). Preparation of stock standards. Preparation of chromatographic working standards. Preparation of extracted sample. Analysis by Gas liquid chromatography (GLC). Determination of organochlorine pesticide residue (Dieldrin): The residues of organochlorine pesticides were quantitavelly determined by comparison with standard solution injected under identical GLC conditions. The reliability of analytical methods was examined by fortifying the examined samples with known quantities of tested pesticides followed by the same procedure of extraction clean up and analysis. Sampling spotting. Development, spraying and exposure of plates.

$$
\begin{gathered}
\begin{array}{c}
\text { Calculation of oganochlorine } \\
\text { residue }
\end{array} \text { (dieldrin): } \\
\text { Pesticide } \\
\text { concentration }(\mathrm{mg} / \mathrm{kg})=\frac{S}{W}
\end{gathered}
$$

Where $S=$ Concentration of pesticide standard (ug/ml) corresponding to the spot of reference pesticide standard. Solution having the same RF value and similar appearance of the unknown spot. $W=$ weight of unknown sample (1.25gm).

\subsection{Determination of organophosphorus pesticide residues (malathion)}

Analytical procedure for determination of malathion was carried out according to AOAC (1990). Preparation of adsorbent layer. Sampling spotting. Development of plates. Spraying and exposure of plate to ultraviolet light source. Calculation and quantitative determination of organophosphorus pesticide residues (malathion): Quantitative determinations were carried out in accordance the following formula:

$$
\log W=\log w s+\frac{A-A s}{A O-A} \log D
$$

Where $\mathrm{D}=$ Dilution factor. $\mathrm{W}=$ Amount of the analyzed material. $\quad \mathrm{Ws}=$ Amount of standard applied. As $=$ Spot area of the standard. $A o=$ Spot area of the diluted analyzed material.

\section{RESULTS}

Results achieved in Table (1) revealed that the mean value of dieldrin in the examined samples of salted sardine, salted Mugil cephalus (Fesiekh) and salted Hydrocynus froskahlii (Mellouha) were 38.2, $164.40 \pm$ $40 \pm 9.31$ and $218.92 \pm 15.07 \mathrm{ppb}$, respectively. The differences between the examined samples of salted fish were not significant (Table, 2). Concerning the dieldrin level, Table (3) declared that $0 \%$, $3.33 \%$ and $10.00 \%$, of the examined samples of salted sardine, salted Mugil 
cephalus (fesiekh) and salted Hydrocynus froskahlii (mellouha), respectively, exceeded the safe permissible limit recommended by EOS (2005) for dieldrin in salted fish (200ppm). Regarding to malathion level, Table (4) indicated that the mean levels of malathion in the examined samples of salted sardine, salted Mugil cephalus (fesiekh) and salted Hydrocynus froskahlii were $0,206.35 \pm 11.59$ and
$318.05 \pm 23.31 \mathrm{ppb}$, respectively. The differences between the examined samples of salted fish were not significant (Table, 5). Table (6) showed that $0 \%, 3.33 \%$ and $3.33 \%$, of the examined samples of salted sardine, salted Mugil cephalus (fesiekh) and salted Hydrocynus froskahlii (mellouha), respectively, exceeded the safe permissible limits recommended by EOS (2005) for malathion in salted fish (300 ppb).

Table (1): Statistical analytical results of dieldrin as organochlorie pesticidal residue (ppb) in the examined samples of salted fish $(n=30)$

\begin{tabular}{lccccc}
\hline Salted Fish & \multicolumn{7}{c}{ +ve samples } & & & \\
& No. & $\%$ & Min & Max & Mean \pm S.E* \\
\hline Sardine & 1 & 3.33 & - & - & 38.2 \\
Mugil cephalus & 3 & 10.00 & 107.9 & 229.3 & $164.40 \pm 9.31$ \\
Hydrocynus froskahlii & 4 & 13.33 & 71.5 & 318.1 & $218.92 \pm 15.07$ \\
\hline
\end{tabular}

S.E* $=$ Standard error of mean

Table (2): Analysis of variance (ANOVA) of dieldrin in the examined samples of salted fish.

\begin{tabular}{ccccc}
\hline Source of variance & D.F & S.S & M.S & F. value \\
\hline Total & 89 & 293144.184 & & \\
Between Products (T) & 2 & 11719.306 & 5859.653 & $1.81^{\mathrm{NS}}$ \\
Error & 87 & 281424.878 & 3234.769 &
\end{tabular}

D.F= Degrees of freedom. S.S = Sum squares. M.S = Mean squares. NS= Non significant differences.

Table (3): Acceptability of the examined samples of salted fish to EOS (2005) * according to their contents of dieldrin $(n=30)$.

\begin{tabular}{lccccc}
\hline \multicolumn{1}{c}{ Salted Fish } & Maximum Residual Limit (ppb)* & \multicolumn{2}{c}{ Accepted samples } & \multicolumn{2}{c}{ Unaccepted samples } \\
& & No & $\%$ & No & $\%$ \\
\hline Sardine & 200 & 30 & 100 & 0 & 0 \\
Mugil cephalus & 200 & 29 & 96.67 & 1 & 3.33 \\
Hydrocynus & 200 & 27 & 90.00 & 3 & 10.00 \\
froskahlii & & & & & \\
Total (90) & & 86 & 95.56 & 4 & 4.44 \\
\hline
\end{tabular}

* Egyptian Organization of Standardization "EOS" (2005) 
Table (4): Statistical analytical results of malathion as organophosphorus pesticidal residue $(\mathrm{ppb})$ in the examined samples of salted fish $(\mathrm{n}=30)$

\begin{tabular}{lccccc}
\hline Salted Fish & \multicolumn{2}{c}{+ ve samples } & & \\
& No. & $\%$ & Min & Max & Mean \pm S.E* \\
\hline Sardine & 0 & 0 & 0 & 0 & 0 \\
Mugil cephalus & 2 & 6.67 & 95.3 & 317.4 & $206.35 \pm 11.59$ \\
Hydrocynus & 2 & 6.67 & 249.4 & 386.7 & $318.05 \pm 23.31$ \\
froskahlii & & & & & \\
\hline
\end{tabular}

S.E* $=$ Standard error of mean

Table (5): Analysis of variance (ANOVA) of malathion in the examined samples of salted fish.

\begin{tabular}{lcccc}
\hline Source of variance & D.F & S.S & M.S & F.value \\
\hline Total & 89 & 309245.025 & & \\
Between Products (T) & 2 & 6938.982 & 3469.491 & $0.998^{\mathrm{NS}}$ \\
Error & 87 & 302306.043 & 3474.782 & \\
D.F= Degrees of freedom. S.S = Sum squares. M.S = Mean squares. NS= Non significant difference
\end{tabular}

Table (6): Acceptability of the examined samples of salted fish to EOS (2005) * according to their contents of malathion $(n=30)$.

\begin{tabular}{lccccc}
\hline \multicolumn{1}{c}{ Salted Fish } & $\begin{array}{c}\text { Maximum Residual Limit } \\
(\mathrm{ppb})^{*}\end{array}$ & \multicolumn{2}{c}{$\begin{array}{c}\text { Accepted } \\
\text { samples }\end{array}$} & \multicolumn{2}{c}{$\begin{array}{c}\text { Unaccepted } \\
\text { samples }\end{array}$} \\
& & No & $\%$ & No & $\%$ \\
\hline Sardine & 300 & 30 & 100 & 0 & 0 \\
Mugil cephalus & 300 & 29 & 96.67 & 1 & 3.33 \\
Hydrocynus froskahlii & 300 & 29 & 96.67 & 1 & 3.33 \\
Total (90) & & 88 & 97.78 & 2 & 2.22 \\
\hline
\end{tabular}

* Egyptian Organization of Standardization "EOS" (2005)

\section{DISCUSSION}

Pesticides are one of the main contaminatns of water sources which are considered the natural environment of fish. On the other hand, fish could be contaminated by pesticides either directly by gill breathing or indirectly through contamination of feeding items. So, it is very important to analyze fish samples to detect the extent of accumulation rate of pesticide residues in fish.
The obtained results in the present study concluded that the examined samples of salted Hydrocynus froskahlii were the most contaminated samples with pesticide residues followed by those of salted Mugil cephalus and salted sardine, respectively. The recorded results of dieldrin levels in Table (1) were higher than those obtained by Mohamed (1997) who found that dieldrin $(\mathrm{mg} / \mathrm{kg})$ in fish muscles ranged from 0.01 to 0.35 , with a mean values of $0.276 \pm 0.029 \mathrm{mg} / \mathrm{kg}$. Also, higher than results which obtained by Eid and Salem 
(2012) who failed to detect dieldrin in the examined samples of Tilabia nilotica and clarias lazera. Regarding to malathion level nearly higher results were recorded than that obtained by Mohamed (1997) who found that malathion in fresh fish ranged from 2.17 to 4.50 with mean value of 3.785 $\pm 0.095 \mathrm{mg} / \mathrm{kg}$. The toxicity of the organophosphorus insecticides depends essentially on metabolic conversion into their corresponding oxygen analogous which acts as direct inhibitor of cholinesterase and acetyl cholinesterase (Maitho, 1992). The inhibition of cholinesterase is irreversible rendering the toxic effects of diazinon persistent until the inhibited enzymes are replaced by newly produced ones (Hayes, 1991). In order to control these pollutants to gain access to salted fish, and to improve the sanitary status of salted fish processing, a good quality raw fish should be used in preparation of salted fish products. Purchase salted fish from reputable sources and markets with a history of providing safe food to customers. High quality spices and additives free from any contaminants should be used. Education and training of food handlers and consumers about harmful effects of chemical residues in foods is the key stone of effective quality control. Application and implementation of Hazard Analysis and Critical Control Point (HACCP) system may be the appropriate solution to ensure quality and safety of such products particularly during preparation.

\section{REFERENCES}

Abdel-Kader, M.A. 1989. Pesticide residue in chicken tissue and its public health importance. Egypt Journal of Applied Science, 4:59-64.

AOAC, 1990. Official method of Association Official Analytical
Chemists for determination of pesticide residue. $12^{\text {th }}$ Ed. Pp. 518. Washington, D.C., USA.

Bedi, J., Jill, J., Joia, B., Sharma, J. 2007. Seasonal variation of DDT and $\mathrm{HCH}$ residues in market goat meat. J. Research 40(2): 247-253.

Egyptian Organization for Standardization and Quality Control (E.O.S.Q.C.) 2005. ESS 1725-1,2,3/2005. for salted fishes.

Eid, A. Salem, A. 2012. Effect of different traditional cooking styles on pesticide residues in fresh Tilapia nilotica and Clarias lazera fish in Gharbia markets.

Hayes, W.J. 1991. Handbook of pesticide toxicology. Academic Press limited. S.A.

Klopov, P.V. 1998. Levels of heavy metals in women residing in Russian Arctic Int. J. Circumpolar Health, 57(1):582858.

Leon, D.S., Bernardett, M.M., Newsome, W.H., Gail, A.P. 1990. Association Official of Analytical Chemistry Pesticide and industrial chemical residues, USA.

Maitho, T. 1992. A study of pesticide residues in bovin fat from Kenya. Zimbabivwe Vet. J. 23(2):67-72.

Mills, P.A., Kamps, L.A., Burke, J.A. 1972. Eluation solvent systems for florsial column clean up in organochlorine pesticide residues analysis. J. Ass. Off. Anal. Chem. 55:124-12.

Mohamed, F.H. 1997. Studies on some insecticidal residues in fish and their public health significance. Ph.D. Thesis (Meat Hygiene). Fac. Vet. Med., Zagazig Univ, (Benha branch). Egypt.

Schafer, K., Kegley, S. 2002. Persistent toxic chemicals in the US food supply. J. Epidemiol. Community Health 56(11): 813-817. 